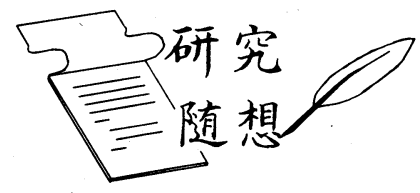

\title{
日鈠一竅, 七日而渾沌死*
}

日本機械学会論文集 (A 編)

71 巻 709 号 $(2005-9)$

$$
\text { 北浩*1 }
$$

\section{So Every Day they Bored One Hole, And on the Seventh Day, Chaos (Hun Tun) Died}

\author{
Hiroshi KITAGAWA*2 \\ ${ }^{* 2}$ Department Mechanical Engineering, Faculty of Engineering, Doshisha University, \\ 1-3 Tatara-Miyakodani, Kyotanabe-shi, Kyoto, 610-0394 Japan
}

Key Words: Continuum Mechanics, Continuous Model, Discrete Model, Multi-scale Analysis, Constitutive Equation, Real Number, Microstructure

螺旋状の階段を上りつつ一巡すると出発点の階に戻 ってしまうという構図一無限階段一を描いた, エッシ ヤーのよく知られただまし絵がある，研究・教育に携 わる仕事から退いて,これまで懸命に努力を積み重ね てきたはずの来し方を少し離れた立場から顧みてみる と, エッシャーのこの絵は, 錯覚ではなく真実を言い 当てているのではないかと思われてくることが多々あ ることに気付く.

\section{序}

大学に入学して最初に受けた数学の講義は実数の定 義から始まった。そしてその内容は, 数直線上に隙間 なく並んでいるという説明からそれまでもっていた実 数のイメージ, 静的で平らな存在, を完全に打ち砕く ものであった．端的に言えば'奈落の底’の開示，いか にして無限に接近するかについて問い, 一定の方法を 取ることを要請(強要？)した上で，(吵間のないはず の)有理数間の吵間にすら恐ろしい深淵が存在すると いう認識を迫るものであった。そのときに同時に学ん だ $\varepsilon-\delta$ 論法との間に奇妙な感覚のずれを感じたこと を思い出す。 $\varepsilon$ $\delta も$ 有限の大きさの平らな量である. ところが例えば, 実数の連続性は無限小の極限に移行 する過程として定義されたはずなのに， $\varepsilon-\delta$ 論法では 有限の空間(時間)認識の下でとらえられるとしてい る？どうもここらあたりで生じた勘違い(錯覚?)

* 原稿受付 2005 年 6 月 20 日.

*1 正員, フェロー, 同志社大学工学部(釆610-0394 京田辺市 多久羅都谷 1-3).

[著者略歴］1940 年生まれ. 主として, 材料力学・計算力学, 特 に, 弾・塑性体の有限変形理論とその応用, 材料の破壊強度を 律する原子レベル構造ダイナミックスの解明な,どの研究に従 事, 2004 年まで大阪大学大学院工学研究科, 現在は同志社大学 工学部に勤務.
が, 以後, 連続体力学を学びその応用研究を進めるに あたって決定的な影響をもってしまったらしい.

ここで問題としたいのは,「連続体モデルと離散モ デルのいずれが物質の微細構造をとらえるのに適して いるか」ということである，最近，頓に耳目を集める ようになった'マルチスケール解析’ の分野で, 研究者 の基本的スタンスとかかわって問われる問題である. ‘離散モデル’とは, 分子動力学法で扱われるような, 物質を原子・分子の集合体ととらえるモデルを一つの 代表例としておくが，それにかかわらずさまざまな粒 子モデルのどのようなものを想像していただいてもよ い.

この問いに対して返って来るまっとうな答えは, “連続体モデルは, 微視的な不均質構造が十分に多く 集まった状態についての平均的な特性を表現するもの であるから，あくまで実際の物質系の近似モデル，あ るいは有効モデルに過ぎない. したがって当然，適 切にミクロ構造(のダイナミクス)が反映された)離散 モデルである”というものであろう.マルチスケール 解析分野の研究論文のまえがきには，必ずといってよ いほどこの趣旨の文章とともに，(マクロスケール解 析に精度・効率がよい)連続体モデルとミクロスケー ル特性が的確に捉えられる離散モデルをいかにして整 合・連成させて解析を進めるかについての主張がなさ れている。このような認識は果たして正しいのであろ うか.

離散モデルは, 有限個の点の (運動の) 集合の上に力 学法則を乗せたものである.一方，実数の集合と同一 視される連続体の自由度は，当然，連続濃度 その内には実に恐ろしい世界を伴っているはずであ る. 実数の集合によって力学法則を表現した連続体モ 
デルがとらえている構造ダイナミクスと, 離散モデル のそれを比較して, 後者のほうがより詳細な情報を与 えるというのが前述の主張である. 単純に考えるとこ のような問題を設定することすらナンセンスと思われ るのに, 比較を行った上で逆の判断がなされている. この主張はどこかおかしい. 50 年程も前に数学の講 義で受けた衝撃が蘇ってくる.どこかに連続体の自由 度を有限に制限してしまって縦しとする錯覚が入り込 んでいるのではないか. 無限小に移行する操作を含意

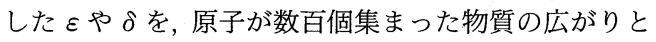
か, 有限要素の最小メッシュサイズに対応させてしま う如き錯覚！ ?

\section{破}

連続体力学は, 19 世紀のはじめに, 古代ギリシャか ら受け継がれた観念的な原子論をミクロスケールモデ ルとして成立した. Euler, Navier, Cauchy, Poisson, ……といた人達によってなされた連続体場の 力学理論の確立は, “物質は無限に分割できるはずがな い’ ‘自然は真空を嫌う’というともに形而上学的な考 え方の対立が，より適切に現象を説明する考え方を認 めるという合理的な視点によって乗り越えられた, 歴 史的に最初の成果といえるかもしれない. Cauchy が 行った弾性理論の研究の遍歴のなかに, 弾性体を粒子 系/連続媒質のいずれと捉えるべきであるのかについ ての悩み(迷い?)を見るにつけ, 先の問題に対する答 えの一つとして連続体モデルは成立したのであり，そ こには有効(近似)モデルを立てるという視点はまった くない.

このようにして得られた連続体場の方程式は, 微細 構造の詳細に鈍感であることが早い時期から指摘され ている.つまり連続体の点(物体点)には, 微細構造は 書き込まれていないのである。それは，逆に考えると， 連続体モデルは多彩な構造を包含しているということ であり，そこに微視的詳細をいかに乗せるのかは解析 者の力量次第であるとも言える. Caprizの表現によ れば, “物体点は強いていえば混沌(Chaos)である’. ここで思い起こすのは, “荘子’にある(天地創造にかか る) 次の故事である.「日鏊一䈓, 七日而渾沌死」. まり,「目, 耳, 鼻, 口という七つのセンサを取付け (るという余計なことをし)たら, 混沌は死んでしまっ た」.混沌であるはずの物体点に浅はかな智恵(マクロ 的な知見）を押しつけて連続体モデルを瀕死の状態に 陥らせ, 微細構造を扱うのに適さないなどと診断を下
してしまっているということではないのか.

完成度の高い連続体力学は物理としてよりも数学理 論として書かれている. 数学理論は演繹によって, 本 来包含できる真実をどんどん縮小し, 本来柔軟性があ ったものを硬直化させてしまう方向で展開される性向 がある。そこに物理 (というよりも経験的知見)が持ち 込まれ, 実用解析に応用される段になると, さらに保 守的になってしまい, “物体とは(その位置が実数の三 つの組と同值である)物体点を要素とする三次元微分 多様体である (Truesdell)' といった出発点での考え方 が, 一次か二次の連続な区分多項式で表される変位場 を求める問題に帰着させて処理される.ここでは, 確 かに物質モデルは微視的不均質性をぬりつぶしたのつ ペりとした構造になっている。

そこで気が付くのは，混沌に七孔を穿つ差配をして いるのは ‘構成式の表式化論’ であり, 安定と効率を優 先させる解析方法が引導を渡す役割を演じているとい うことである. 連続体力学における構成式の役割は, 字義のとおり ‘構成論的に現象を見る枠組みを与える こと’であり, それに過度に頼ることは, ‘あらかじめ 予想をしたとおりの解を引き出す手続きを記述するこ と’を行っているにすぎないと考えるべきであろう。

\section{急}

本来, 連続体モデルは, 多様な微視構造を乗せるこ とができる台であり，その上に現れる表徵は自然界の 実在を記述する述語的なものとして捉えるべきもので はなかろうか. 構成式を荘厳に飾り立てることによっ て連続体モデルに強いて語らしめ, 今度はそれを主語 として語ったときに, 混沌は死に, 解析者の姿を忠実 に写すだけの真っ平らな唯の鏡になってしまう.

さまざまな離散モデルが提案され，それらが実にリ アルなミクロ世界を描き出すことを示した多くの報 告, 連続場の方程式を差分近似(して離散化)して取扱 うことによって初めてとらえられるカオス現象の報告 などに接するに付け, “連続体モデルには, (無限に)多 様な微細構造(とそのダイナミクス)が繰り込まれてい る.それを引き出せるかどうかは (近似) 解析の方法の 問題である’との思いを強くする.

もう一巡，無限階段を上ったときには，何を考えて いるであろうか. もうそのような時は巡って来ないか もしれないが. 